\title{
Stamped from the Beginning, The Definitive History of Racist Ideas in America
}

Review Number: 2165

Publish date: Thursday, 7 September, 2017

Author: Ibram X. Kendi

ISBN: 9781568584638

Date of Publication: 2016

Price: $£ 30.00$

Pages: 592pp.

Publisher: Nation Books

Publisher url: http://www.publicaffairsbooks.com/book/stamped-from-the-beginning/9781568584638

Place of Publication: New York, NY

Reviewer: Richard King

Paradigm shifts in historiography seem to come all at once rather than being spaced evenly along the disciplinary trajectory. The last such shift in writing about slavery and race (including civil rights) in the United States came between the late 1950s and the mid-1970s. It looks now as though we are in the midst of another re-casting of the framework of assumptions and vocabulary of concepts that US historians bring to the study of these critical topics. Add to that the fact that Colson Whitehead's novel, Underground Railroad (2016), won both a Pulitzer Prize and a National Book Award, while several recent Oscar nominees for 2017 were films - Moonlight, Fences, Hidden Figures, and Loving - that explored various dimensions of the African-American experience over the last half-century. In fact, the book under review here, Ibram X. Kendi's Stamped from the Beginning, won the 2016 National Book Award in Nonfiction.

Kendi is an academic historian, who recently shifted his base from the University of Florida to the American University in Washington, DC. It is relatively rare for a work of academic history to win a non-academic book prize such as the National Book Award, though academic historians have been more successful with Pulitzer Prizes probably because the Pulitzer includes an award specifically in history. Some of this may have to do with the supposed tendency of academic writing to belabour obscure points and to smother major points with qualifications and caveats (and footnotes). However, Kendi's book is clearly written and often polemical in tone. It is not exhaustively researched and contains little or no historiographical skirmishing, and in fact I don't think there is enough of the latter, considering the contentious material he is dealing with.

In Stamped from the Beginning, Kendi seeks to do two big things. First, he traces out the historical trajectory of slavery and race in North America, specifically of the future United States, from circa 1400 down to the present. He divides this story into five sections, with each section organized around a representative individual - Cotton Mather, Thomas Jefferson, William Lloyd Garrison, WEB DuBois, and Angela Davis. Clearly, these figure had a different personal history of engagement with slavery, race, and civil rights. Not every chapter in each section deals directly with the iconic figure presiding over it, but this organizational strategy gives shape and focus to a massive amount of material.

Dividing the historical narrative into five parts also allows Kendi to take on a second task: the exploration of 
three fundamental concepts - Racism, Assimilation and Antiracism - that he sees as encompassing American attitudes toward race.(1) This analytical dimension gives the historical story a moral and political point, rather simply being another depressing story of slavery and race in the New World, while the body of the historical narrative puts flesh on these bare-boned abstractions Kendi contends are vital to understanding race in America. At times these three concepts seem too abstract and one-dimensional. The constant labelling of historical figures in terms of how they fit into one (or more) of the big concepts can work at cross-purposes with his exploration of the complicated nature of race and racism - that 'ever changing same' - in the United States. It is also not clear whether these three concepts apply only within the United States; if so, why? And yet, Kendi's three concepts take on layers of meaning as the book moves from past through the present and into the future. He also coins terminology - for instance, 'gender racism' - to identify historical examples of what Kimberle Crenshaw has called 'intersectionality'. Overall, then, Stamped from the Beginning sometimes seems like a work of history with a razor sharp polemical edge; at other times, it reads like an extended moral-polemic, fleshed out and exemplified by historical examples. History as ethics teaching by example? Beyond that Kendi's book also exemplifies the way that the post-1945 study of race and racism in the US has tended to focus on race and racism as ideas, thus suggesting that the study of race in the US has been a branch of intellectual history.

Not surprisingly, the most controversial aspect of the book has to do with Kendi's exploration of the three big concepts. Racism and Antiracism seem relatively simple. The latter arises from the belief that the enslavement and then subordination of blacks to whites in United States history is a function of white racism: 'racial discrimination is the sole cause of racial disparities in this country and in the world at large' (p. 10). For Kendi, the way to abolish racial disparities is, first, to end discrimination and, second, to provide the resources to close the gap between white and black Americans. The Racist position is that racial disparities are either natural or deeply cultural in nature. Historically, racism came into existence to justify the oppression inherent in the enslavement of people of African descent and thus to protect self-interest (generally economic). Finally, the most problematic term is Assimilation, which is Kendi's name for the belief that African-American culture is allegedly 'pathological' (Gunnar Myrdal's term) and hence inferior. What it has implied historically is that time is needed for African Americans to be incorporated into the allegedly superior white culture as cultural equals. More contentiously, Kendi insists that Assimilation is not a value-neutral process of exchanging one set of values, life-style, traditions and behaviour for another. It is actually a form of Racism, which privileges white culture over African or African American culture. I will return to this issue later.

What is it that Kendi's approach challenges? Here we need to remember the tenets of the consensus on racism and race that emerged after the Second World war in the wake of the attempted genocide of European Jewry, a racially inflected war between the Allies and Japan, the decolonization of the so-called Third World, and, above all, the on-going presence of, then challenge to, racial segregation in the United States. The first tenet, which Kendi does not challenge, is the modernity of the concept of race itself. It was the yoking together of New World chattel slavery with the well-nigh exclusive use of Africans as slaves that created the strong link between the idea of race and the idea that there was a hierarchy among races. To justify the development of a slave system required a concept of unified difference and inferiority of the Africans.

When that ideology emerged in coherent form is hard to say. In White Over Black (1968), Winthrop Jordan thought it took two plus centuries for systemic racism to emerge by the mid-18th century, but Kendi argues that it emerged a good bit earlier.(2) Still, he agrees that race and racism were conceptual realities that emerged in, and were an integral part of, of the modern world. They were not aberrations or regrettable historical remnants from a less enlightened time. Kendi also accepts the contemporary view that the phenomenon of racism antedates the concept of race. Thus, the need to demote Africans to sub-human status led to the idea of race as that something - an essence or quality or set of capacities - that disqualified them from fully-human status.

Beyond that the modern concept of race was organized around the view that race was a biological concept, 
not a cultural, religious or climatological one. It was essentially secular, intellectually undergirded by a late 19th-century racialized Darwinian consensus that saw the essence of history to consist in racial conflict. Opponents of Darwinism, even religious ones, were not all wrong when they stressed social Darwinism's positing of social and historical conflict as a driving force in human affairs. It was the main rival to the Marxist view of history as class struggle. W. E. B. Du Bois was correct in The Souls of Black Folk (1903) when he contended that 'the problem of the Twentieth Century is the problem of the colour-line'. Colour differences signified racial and cultural differences incapacities among human groupings. As Hannah Arendt also emphasized, anti-Semitism became racialized in the late 19th century as well. No longer was it primarily a religious or cultural set of beliefs. $(1)$

Kendi covers much of this directly or obliquely, but he is not interested in doing heavy duty or text-based intellectual history.In fact, Kendi does not really emphasize the importance of the biologization of race. When the early slave trade flourished, religion was used to define the essential difference between Europeans and Africans. Secular stalwarts of the Enlightenment such as Kant and Hume tended to see climate as the crucial causal factor in forming distinct races, a view that was widely accepted in its time. But in focussing most of his attention on the pernicious impact of Assimilation, which actually rejects biologically based racism, Kendi all but implies that Assimilationist ideologies have been as dangerous, or more so, than straightforward (white) Racism based on alleged biological differences. On his view, Assimilationist theories feign sympathy for, while assuming the actually existing inferiority of, African American life and culture under the conditions of oppression. It is on this point that Kendi's book is most radical and most challenging.

This means that Kendi's Stamped from the Beginning is also witheringly critical of the Assimilationist emphasis on the efficacy of moral and educational tutelage to hasten along racial assimilation, what he calls moral 'suasion' and racial 'uplift'. Men and women of good will and from both races in the 19th century and 20th century - even down to now - thought they were working for the eventual incorporation of former slaves and their descendants into white mainstream institutions, when the effect of what they were doing, claims Kendi, was to confirm African Americans in their unequal status and power. Indeed, Kendi is also lukewarm on the historical evidence for massive changes of white attitudes on the question of race through educational or moral persuasion. Understandably, what he objects most to is the Assimilationist idea that Black culture was/is inferior and should be abandoned when compared with the strengths of white culture. For Kendi, Black Americans have been psychologized (as 'damaged') and moralized over (Black men as feckless and Black mothers as 'loose' sexually) and allegedly rendered dysfunctional by the Black family to within an inch of their lives. As a challenge to this belief, which flourished in the early 1960s but which came under attack by the latter years of that decade, Kendi insists that the disparities between white and black ways of life have arisen from white discrimination, the results of which have been 'inferior opportunities and bank accounts for Black people'. But Black people are 'not an inferior social group' (p. 492). More generally, the damage to African-American lives that Kendi wants to address is economic and social not cultural and psychological.

The problem here is the incredibly complicated nature of the Assimilationist position. Take the question of affirmative action, for instance. Kendi praises President Lyndon Johnson's Howard University address of 4 June 1965 when he spoke of the unequal starting position in life chances between Blacks and Whites. This was, according to Kendi, an Antiracist justification for what became affirmative action. Yet from another angle, affirmative action seems like a classic Assimilationist measure, a way of paternalistically granting African Americans access to cultural and educational goods but implying that they cannot achieve them on their own. Are quotas and 'set-asides' brave Antiracist measures or ways of treating Black Americans as permanent wards of the state? Whatever the case, Kendi's Antiracism is interested in the correction of disparities in matters such as education, housing, access to medical care, while rejecting the notion that long centuries of enslavement, followed by a long century plus of institutionalized discrimination and disfranchisement, have helped create a culture marred by 'spoiled identities' (Erving Goffman's term) and a suspicion of a 'work ethic' that has never really worked. The problem for Kendi here is that some of his Antiracist heroes such as Malcolm X also believed in long-term effects of White oppression on Blacks. As 
did W. E. B. DuBois up to the 1930s, a view that Kendi calls 'class racism'. Given the inseparability of body and mind, the overlapping of economic and cultural spheres, it isn't clear how Kendi can keep damage confined to one sphere or imagine that the effects of oppression will disappear relatively shortly after slavery is abolished or segregation is ruled unconstitutional. Clearly he needs a more complex notion of Assimilation.

For instance Kendi quite rightly reminds us at every turn that Assimilationist ideologies have been pervasive among the educated of both races, including national leaders. Lincoln is famously hard to get straight, since he was firmly convinced of the moral wrongness of slavery but was never clear about whether he believed in racial equality. Kendi also emphasizes the undeniable fact that working militantly against slavery was compatible in most people's minds with the idea of racial inequality. The great Abolitionist, William Lloyd Garrison, was fearsome and fearless in his attacks on slavery. But he was one of Kendi's Assimilationist racists. In fact, the historical ranks of Assimilationism are replete with those we usually consider fighters against racial injustice, discrimination and segregation. The list includes Richard Wright, Gunnar Myrdal, E. Franklin Frazier, Kenneth and Mamie Clark, Harper Lee, Daniel Patrick Moynihan on down to Barack Obama (some of the time). Black and White together, indeed! The list could go on, and would, he tells us winningly, have to include Ibram Kendi before he began the research that went into the making of Stamped from the Beginning. He is aware that this re-labelling of friends and enemies needs more discussion, I think, and I wish he had done more of it in the book. For instance, he does try to talk about Racism, Antiracism and Assimilation as ideological and institutional positions not individual or group psychological traits. For instance, it is better to say that Garrison or DuBois held Racist views than that one or the other was a racist.

There is yet another essential tenet in the catechism of modern American Antiracism that Kendi calls into question - what DuBois called 'double consciousness'.(4) Kendi observes, for instance, that 'Assimilationists still wanted to keep him [Martin Luther King] in the doubly conscious dreams of 1963', while 'King's death transformed countless doubly conscious activists into singly conscious antiracists' (p.406). This suggests that, for Kendi, double consciousness is really an Assimilationist concept, and contrasts with what 'antiracist Black Power compelled' : 'the controversial search for new standards ... for Black people looking at themselves through their own eyes' not through imagined white eyes (p. 406). This powerful interpretation of double consciousness reveals a problem with the master/slave dialectic in Hegel's Phenomenology of Spirit. It is built on the assumption that recognition of the slave as fully human must come from the master himself. When translated into American reality, it means that the white oppressor, not black fellow slaves, remains the significant other in African-American consciousness. Yet, abandoning the self-other dialectic of identity formation entails a loss of complexity of consciousness and of self-knowledge on both the individual and group level. Kendi thus raises the very important question: is it possible to retain the idea of double consciousness without thereby assuming/internalizing a 'spoiled' identity'?

There is something else problematic about the concept of Assimilation as Kendi uses the term. Generally, we understand assimilation to refer not just to a kind of passive, imposed incorporation into a new culture but also to a process of selection from, and re-configuration of, the hegemonic culture by the oppressed. For example, the spirituals, the 'sorrow songs', did not passively emerge from the incorporation by African Americans into a European religious ideology alone. Rather they involved an active selection from, and reconfiguration of, the dominant religion of Christianity. This second meaning of assimilation makes it a more ambiguous, richer and also a historically more accurate term, than Kendi's passive idea of Assimilation allows. I am also reminded of the distinction Hannah Arendt drew between 'pariahs' and 'parvenus' .(5) The former confronts the dominant, hegemonic culture from a position of independence and may choose selectively, distort and parody aspects of the dominant culture. It thinks of assimilation as the adoption of aspects of the dominant culture but not a passive acceptance of everything the dominant culture has to offer. The parvenu type thinks of assimilation as a worth the price of abandoning one's own culture for acceptance into the dominant culture and society. The pariah chooses cultural autonomy, while the parvenu accepts culture of the arriviste.

For all its stimulating provocations, Stamped from the Beginning needs a transnational and/or comparative 
concept of culture. Has assimilation been the same in the West Indies or Britain or in France as it has been in the United States? What about the new levels of mutual political and culture recognition involved in being part of a Black Atlantic? The strengths of Stamped from the Beginning, lie in the areas of economics and politics, but if Kendi is going to abandon the idea of double consciousness, he needs a much stronger, more resilient, and active notion of cultural identity. Finally, I am also worried about Kendi's exclusion from the Antiracist camp of many figures who have been of absolute importance in what Vincent Harding once called 'the Great Tradition' of African-American protest. At times, Kendi can sound like he is in search of heretics rather than interested in exploring the complex realities of his three big concepts. But that way lies the stifling, not the stimulation, of ideological and historiographical debate.

\section{Notes}

1. I will capitalize the first letter of the three concepts when I am discussing Kendi's use of them, but use the lower-case when I am referring to one or more of the concepts in general.Back to (1)

2. Winthrop D. Jordan, White Over Black: American Attitudes toward the Negro, 1550-1812 (Chapel Hill, NC, 1968). Back to (2)

3. Hannah Arendt, The Origins of Totalitarianism (2nd ed., Cleveland, OH, 1958). Back to (3)

4. See chapter one of W. E. B. DuBois, The Souls of Black Folk (1903).Back to (4)

5. Hannah Arendt, 'The Jew as Pariah (1944)', in The Jewish Writings, ed. J. Kohn and R. Feldman (New York, NY, 2007). Back to (5)

\section{Other reviews:}

Guardian

https://www.theguardian.com/books/2017/jul/03/stamped-from-beginning-definitive-racist-ideas-americaibram-x-kendi-review [2]

Washington Post

https://www.theguardian.com/books/2017/jul/03/stamped-from-beginning-definitive-racist-ideas-americaibram-X-kendi-review [2]

Times

https://www.thetimes.co.uk/article/review-stamped-from-the-beginning-the-definitive-history-of-racist-ideasin-america-by-ibram-x-kendi-3g2390xbz [3]

Kirkus Reviews

https://www.kirkusreviews.com/book-reviews/ibram-x-kendi/stamped-from-the-beginning/ [4]

Source URL:https://reviews.history.ac.uk/review/2165

\section{Links}

[1] https://reviews.history.ac.uk/item/272954 [2] https://www.theguardian.com/books/2017/jul/03/stampedfrom-beginning-definitive-racist-ideas-america-ibram-x-kendi-review [3] https://www.thetimes.co.uk/article/review-stamped-from-the-beginning-the-definitive-history-of-racistideas-in-america-by-ibram-X-kendi-3g2390xbz [4] https://www.kirkusreviews.com/book-reviews/ibram-Xkendi/stamped-from-the-beginning/ 